\title{
Earth science mini-lessons: A service-learning strategy for improving attitudes toward science of preservice elementary teachers
}

\author{
K. Thompson \\ B. R. Bickmore \\ Charles R. Graham \\ charles.graham@byu.edu
}

S. C. Yanchar

Follow this and additional works at: https://scholarsarchive.byu.edu/facpub

Part of the Educational Psychology Commons

\section{Original Publication Citation}

Thompson, K., Bickmore, B. R., Graham, C. R., \& Yanchar, S. C. (27). Earth science mini-lessons: A service-learning strategy for improving attitudes toward science of preservice elementary teachers. Journal of Geoscience Education, 55(3), 228-234.

\section{BYU ScholarsArchive Citation}

Thompson, K.; Bickmore, B. R.; Graham, Charles R.; and Yanchar, S. C., "Earth science mini-lessons: A service-learning strategy for improving attitudes toward science of preservice elementary teachers" (2007). Faculty Publications. 250.

https://scholarsarchive.byu.edu/facpub/250

This Peer-Reviewed Article is brought to you for free and open access by BYU ScholarsArchive. It has been accepted for inclusion in Faculty Publications by an authorized administrator of BYU ScholarsArchive. For more information, please contact ellen_amatangelo@byu.edu. 


\section{Earth Science Mini-Lessons: A Service-Learning Strategy for Improving Attitudes Toward Science of Preservice Elementary Teachers}

\author{
Kirsten Thompson \\ Barry R. Bickmore \\ Charles R. Graham \\ Stephen C. Yanchar
}

\author{
Department of Geological Sciences, Brigham Young University, Provo, UT 84602 \\ Department of Geological Sciences, Brigham Young University, Provo, UT 84602 \\ Department Instructional Psychology and Technology, Brigham Young \\ University, Provo, UT 84602
}

Department Instructional Psychology and Technology, Brigham Young University, Provo, UT 84602

\begin{abstract}
Science instruction in elementary school classrooms is frequently lacking in the United States. One factor that impacts the amount and quality of science instruction is teacher attitudes toward science. The Earth Science Mini-Lesson Project is a strategic program created to help improve preservice elementary school teachers attitudes toward science in a one-semester college class. Students participating in this project create earth science mini-lessons on topics taken from the Utah Core Curriculum Standards and teach them to elementary students at a local Title I grade school. Attitude survey results from both semesters showed that this service-learning outreach program positively affected students' attitudes after minor adjustments to the project organization. This is a simple, inexpensive, yet effective, project that can be implemented in a one-semester college science course for preservice elementary teachers that can help improve their attitudes toward science.
\end{abstract}

\section{INTRODUCTION}

Science is often poorly taught or neglected altogether in U.S. elementary schools (Abell and Roth, 1994; Manner, 1998), even though school boards and administrators voice their support for its inclusion in the curriculum Science teaching reform efforts (NRC, 1996; NSF, 1997) are being made on the elementary curriculum level and core requirements may be increased through legislation (NCLB, 2001), but the effects of these efforts will be diluted if teachers do not teach the material. Teachers emphasize subjects they both understand and enjoy (Westerback, 1982, 1984). Many studies have shown that the cure for poor science instruction is not simply more content knowledge among teachers; attitudes of the teachers toward science must also be improved (Dobey and Schafer, 1984; Kobolla and Crawley, 1985; Mestre, 1991). Additionally, poor teacher attitudes can negatively influence the attitudes toward science of their students (Greenblatt, 1962; Haladyna and Schaugnessy, 1982; Kahle, 1984; Stollberg, 1969). This influence can be pivotal, since many young students decide whether they like science before they leave elementary school (Kahle, 1996; Roth and McGinn, 1998).

If an intervention can be made to affect teacher attitudes toward science, the ideal time to attempt a change of attitude is at the university level where they take classes as large cohorts, but the window of opportunity is small. Preservice elementary teachers typically must complete $2-4$ semesters of science courses (Lusk et al. 2006), and these classes will most likely be their last exposure to natural science before they begin teaching (Hannula, 2003). However, steps can be taken in these few courses to encourage positive attitudes toward science for the next generation of elementary education teachers.

Preservice teacher attitudes toward science can be influenced by positive experiences in high school and university science courses (Cantrell et al., 2003; Ginns and Watters, 1996). Generally, students entering these courses view science as an established group of facts that must be tortuously memorized and then regurgitated on exams (Havholm, 1998; Slater et al., 1999; Tewksbury, 1998; Yager, 2000). They do not view science as part of their everyday lives and feel alienated from it (Coburn and Loving, 2002; Dworkin, 2001; Holton, 1994). To change such attitudes in a university setting, professors must include hands-on, stimulating, non-threatening experiences in their courses (Rischbieter et al., 1993; Slater et al., 1999; Westerback and Long, 1990), which can seem a daunting task to a classically trained scientist. The enhancement must be simple and inexpensive to implement, yet effective. However, many professors have discovered creative ways to expose students to positive science experiences in their required science courses, thus enhancing attitudes and learning.

Some professors have found success by changing the traditional teaching methods and enhancing positive science experiences in their elementary education science methods courses. For example, a number have employed field experiences to expose students to hands-on, real-world science research (Brown et al., 2001; Hall and Buxton, 2004). Drawing, painting, sculpting and other artistic projects can educate preservice teachers about creativity in science practice (Cherif and Gialamas, 2000; Drummond, 1999; Metzger, 1996; Morris et al., 2000; Wright, 2000). Others have utilized language arts approaches such as writing stories, making puzzles, and reading children's literature (Kusnick, 1999; Lusk et al., 2006; Osborne and Brady, 2001; van Zee and Roberts, 2001). Other unusual methods include role play, personification, and science forums (Drummond, 1999; Havholm, 1998; Rule, 2005) in addition to enhancing the traditional methods lab with more inquiry-based learning (Gosselin and Macklem-Hurst, 2002; Hannula, 2003; Slattery, 1996).

Student projects such as these are most effective when the student product is perceived to be of some use outside of the classroom, e.g., a final product of publishable quality (Badura et al., 2000; Bull and Davis, 1980). Another approach that has been used to help students feel their projects are more useful is to involve a service-learning component (Erickson and Anderson, 1997; Madden, 2000; Payne, 2000). Service learning can 


\section{COLLABORATIVE WORK PLAN}

\begin{tabular}{|l|l|l|}
\hline Nime & Phon: & email \\
\hline & & \\
\hline & & \\
\hline & & \\
\hline
\end{tabular}
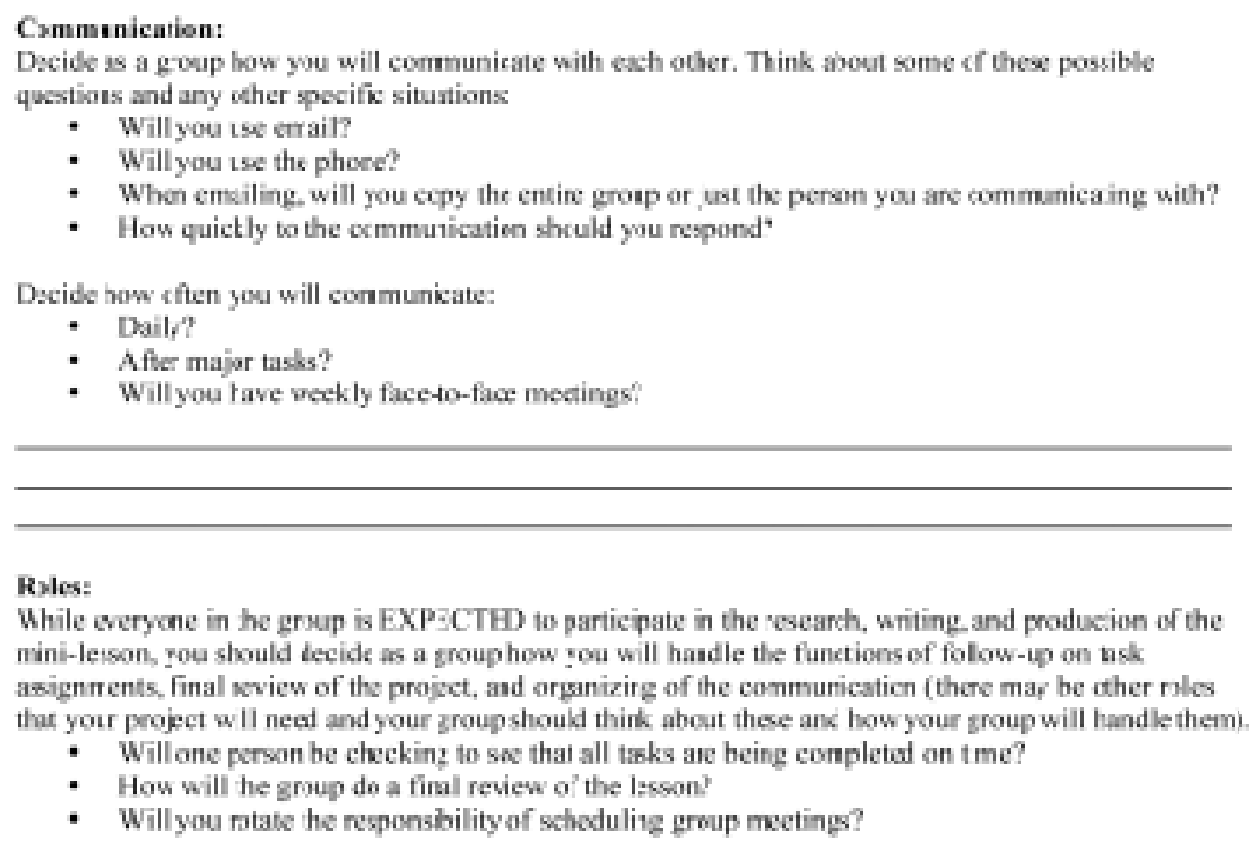

\section{Performance:}

It is crucial that all members of the group attend the labs and all group neetings. How the group will wort stould be decided apon a this point.

- How can werycne be involved ir content research?

- How can you diride the productien tasks up shilestill ixcluding all in the development?

- How will you hold all members responsible for attendance and task completion?

Figure 1. Form designed to help student teams create a collaborative work plan. Inclusion of the collaborative work plans during the second semester of the mini-lesson project helped ease some of the frustration students felt about working in groups.

involve collaboration with local government and civic leaders or interactions with grade schools or the public at large (Hall and Buxton, 2004; Wagner and Caldwell, 2000). These interactions are effective teaching tools that contribute to the growth, learning and social conscience of the students (Erickson and Anderson, 1997). Attitudes and knowledge can be enhanced because the students are participating in active, constructive learning that has meaning outside of a student's immediate quest for grades (Beiswenger et al., 1998; Fones et al., 1999; Payne, 2000). In short, students are excited and motivated to do something "real."

In this paper we report on a simple and easy-toimplement service-learning project implemented in an earth science course for preservice elementary education majors. Students in this course created science mini-lessons tied to the Utah Core Curriculum Standards and taught the lessons to students at a local Title I elementary school. Attitude scores (as measured by surveys described below) increased both semesters, most substantially during the second semester after we made minor revisions to the assigned project.

\section{METHODS}

In order to study the effect of this service-learning project, we tried to implement the project in a way compatible with our particular classroom setting and utilized effective assessment tools to evaluate the project outcomes. 


\section{MINI TEACHING GUIDE}

Ask yourself these questions about your lesson:

\section{- Do I present a real-world problem?}

- Do I make the students think about relevant prior knowledge or experience?

- Do I demonstrate and show rather than merely tell the information to be learned?

- Do I give the students the opportunity to practice and apply the new knowledge or skill?

- Do I show the students ways to use the new knowledge or skill in their everyday lives?

Based on Dr. David Merrill's "First Principles of Instruction." hatp://waw_indianaedu'-tedfrick/aect2002/irstprinciplesbymerrill.pdf

Figure 2. Mini teaching guide provided to students to give them guidance on what makes a good lesson. Although nearly all of our students had declared elementary education or early childhood education as their majors, most had not yet been formally accepted into the program. Therefore, they had not yet had any pedagogical training. During the first semester of this project, we discerned that some of the students were prone to apprehension about the quality of their lessons before the presentations. This guide was meant to alleviate those fears. See full guide at http://www.geology.byu.edu/ps110b/ teachingguide.htm

Participants - Physical Science 110B (PS 110B) is a one-semester earth science course for preservice elementary education majors. Approximately 120-140 students per semester take this required course in their sophomore year; the vast majority of these students (about 98\%) are female and have only had high school science courses, and possibly one university course on basic chemistry and physics, before attending this class. The professor presents two 50 minute lectures per week and the students break off into nine laboratory methods sections instructed by graduate student TAs for another two 50 minute sessions per week. One hundred students participated in the study for the Fall 2004 semester and 103 participated in Winter 2005.

Implementation - In a previous study of the same course, Lusk et al. (2006) attempted to improve student attitudes toward science by implementing an experiment where participants in the treatment group authored a science storybook, which was then illustrated by a Visual Arts student and published on the Internet. The control group did not author storybooks but participated in the standard class project of creating a science mini-lesson, which was then presented to a small group of children of varying ages. They found that attitudes in the treatment group did improve significantly over the control group as measured by the Attitude Toward Science Survey (ATSS,) a four-response Likert-type survey with 11 positively worded statements about the respondents' feelings toward scientists and the processes of learning and understanding science (Lusk et al., 2006).

For our study, we attempted to improve the attitude toward science of all the students in this course, not just a select treatment group as Lusk et al. (2006) had done. In place of a control group, we compared our results from the ATSS to the control groups in the Lusk et al. (2006) study.

In Fall semester 2004 and Winter semester 2005 all students in PS 110B were required to create mini-lessons on a topic chosen from a list of science principles in the Utah Core Curriculum Standards. The lessons created ranged from a simple "dance" about weather ("Observe and describe weather" from 2nd Grade Standard 3, Objective 2) to more complex discussions about erosion ("Students will understand that chemical and physical changes occur in matter" from 5th Grade Standard I). We assigned a grade level to each of the lab sections and students grouped themselves into teams of three or four. On a day near the end of the semester, the preservice teachers visited a local grade school and presented their lessons to the children, one grade level at a time. This activity was held in the school's gymnasium and cafeteria, where the university students set up their displays and activities on large tables and the grade school students, in groups of 5-8, rotated every 5-6 minutes to the next lesson.

As a resource for the preservice teachers, we developed a web site with some logistical information, along with suggestions and links to information that the students could use to create their lessons. After the first semester we found the groups did not always work together well and the students, not having any pedagogical training at this stage, did not feel secure in creating lesson plans. We then added a group planning sheet, which walked the students through a process to help facilitate positive collaborative working skills (Figure 1), and a teaching guide (Figure 2), which summarized five basic principles of instruction and gave many examples to help them plan successful lessons. All of these resources can be found, among many other resources, on the project web site, at http://www. geology.byu.edu/ps110b/presentation.htm.

Assessment - To evaluate the effectiveness of the service-learning project, we needed an assessment tool that would enable us to compare the attitudes toward science of the preservice teachers at the beginning and end of the semester. This was measured using the Attitude Toward Science Survey (ATSS), a four-response Likert-type survey with 11 positively worded statements about the respondents' feelings toward scientists and the processes of learning and understanding science (Figure 3). The minimum score possible on this 34 point survey was 11; the maximum was 44 . This survey was adapted by Lusk et al. (2006) from a survey created by Thompson and Shrigley (1986) to assess science attitudes. The ATSS was given the first and last day of the course and the results were compared.

The survey given on the last day of class contained an additional, open-ended question, that asked students to specifically list the aspects of the course that most positively or negatively affected their attitudes toward science. Several themes in the responses to these survey questions were identified, and all of the responses were coded according to the theme identified and whether it was listed as a positive or negative impact factor. 
Instructions: Respond to the following statements by circling:

\section{4 if you strongly agree, \\ 3 if you agree, \\ 2 if you disagree, and \\ 1 if you strongly disagree.}

1. Science is fun

2. I have good feelings toward science.

3. I enjoy science courses

4. I am well prepared to teach science to my future studentsandor children.

5. I really like scienos.

6. Mos: people can understand the work o' science.

7. I think scientists ane neat pesple.

8. I ustally look forward to $\mathrm{my}$ science slass.

9. We dô a ôt of fun activities in science classs.

10. We cover interesting topies in science class.

11. I want to enccurage my future stadenis and/or children to learn more science.

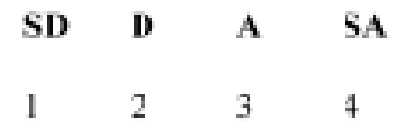

$\begin{array}{llll}1 & 2 & 3 & 4\end{array}$

$\begin{array}{llll}1 & 2 & 3 & 4\end{array}$

$\begin{array}{llll}1 & 2 & 3 & 4\end{array}$

$\begin{array}{llll}1 & 2 & 3 & 4\end{array}$

$\begin{array}{llll}1 & 2 & 3 & 4\end{array}$

$\begin{array}{llll}1 & 2 & 3 & 4\end{array}$

$\begin{array}{llll}1 & 2 & 3 & 4\end{array}$

$\begin{array}{llll}1 & 2 & 3 & 4\end{array}$

$\begin{array}{llll}1 & 2 & 3 & 4\end{array}$

$\begin{array}{llll}1 & 2 & 3 & 4\end{array}$

Figure 3. Attitude Toward Science Survey (ATSS) created by Lusk et al. (2006), and used in this study.

\section{RESULTS AND DISCUSSION}

This Earth Science Mini-lesson Project was easy to implement, involved no monetary cost, and made a positive difference in preservice science teacher attitudes. However, this difference was only evident when the project was refined to fit the learning style of the students.

The ATSS results from our first semester (Fall 2004) showed no statistically significant improvement between the pretest (Mean $=30.15, \mathrm{SD}=4.16)$ and the posttest $($ Mean $=30.89, \mathrm{SD}=4.51), \mathrm{t}=-1.88, \mathrm{p}<.063$. This small increase (0.74 points) is not significant at the $95 \%$ confidence level, and is similar to that shown by the control groups during the study by Lusk et al. (2006). On the other hand, qualitative data from student questionnaires seemed to indicate some promise in the concept. When the students were asked which aspects of the class most positively or negatively affected their attitudes toward science, they mentioned the service-learning project most frequently as a positive influence (Table 1). What went wrong?

First, we believe that inadequate guidance for group work was an issue. For instance, one student wrote "all three of us work, and it was really difficult to find even a small block of time that worked for all of us." Another 


\begin{tabular}{|c|c|c|}
\hline Topic & $\begin{array}{c}\text { Number of positive } \\
\text { responses }\end{array}$ & $\begin{array}{c}\text { Number of negative } \\
\text { responses }\end{array}$ \\
\hline Teaching the mini-lesson at the elementary school & 42 & 0 \\
\hline The lab and experiments/experiences associated with the lab & 34 & 4 \\
\hline Learning about a real-world topic and its relevance to, and impact \\
on, everyday life & 27 & 1 \\
\hline The attitude of the teacher or lab assistants & 23 & 1 \\
\hline The rock and mineral identification final exam & 5 & 10 \\
\hline The course textbook & 4 & 1 \\
\hline
\end{tabular}

Table 1. Summary of answers to the open-ended, qualitative survey question given with the Fall Semester 2004 ATSS posttest. The question asked participants to list and explain which aspects of the class most positively or negatively affected their attitudes toward science. Note that the mini-lesson project was most frequently cited as something that positively impacted attitudes.

\begin{tabular}{|c|c|c|}
\hline Topic & $\begin{array}{c}\text { Number of positive } \\
\text { responses }\end{array}$ & $\begin{array}{c}\text { Number of negative } \\
\text { responses }\end{array}$ \\
\hline Teaching the mini-lesson at the elementary school & 46 & 0 \\
\hline The lab and experiments/experiences associated with the lab & 20 & 7 \\
\hline Learning about a real-world topic and its relevance to, and impact \\
on, everyday life & 26 & 0 \\
\hline The attitude of the teacher or lab assistants & 20 & 5 \\
\hline The rock and mineral identification final exam & 3 & 16 \\
\hline The course textbook & 0 & 1 \\
\hline
\end{tabular}

Table 2. Summary of answers to the open-ended, qualitative survey question given with the Winter Semester 2005 ATSS posttest. The question asked participants to list and explain which aspects of the class most positively or negatively affected their attitudes toward science. Note that the mini-lesson project was once again the most frequently cited factor that positively impacted attitudes

wrote that "the work load was not fairly distributed [among the group members.]"

Second, Sloan et al. (2004) showed that the pre-service elementary teachers they studied tended to be "closed learners," meaning that they only felt comfortable with assignments that had firm boundaries, rubrics, and examples to guide them. They disliked ambiguity and preferred clearly stated and detailed directions. In our case, this turned out to be a limiting factor. Many students complained that they did not have enough information about the exact sizes of the student groups they would be teaching (they were only given approximate numbers, ) the sizes of the tables they would have at their disposal, wall space available, etc. For example, one student wrote, "It would have been nice to know exactly how our table would be set up. They were tall tables-difficult for children to see [the lesson materials] without standing up and getting close." (They were the normal, fold-out tables found at most schools.) Our impression was that a large fraction of the students felt very frustrated about the lack of such logistical information, and this detracted from their excitement leading into the presentations.

The net effect of these frustrations was that many of the preservice teachers did not really become excited about the project until they were at the grade school, giving their lessons. Since this occurred at the end of the semester, the potential positive impact of the project was not fully realized. One student commented, "Being able to work with elementary children and see firsthand the effect teachers have on their students affected me in the most positive way. It allowed me to be in an actual teaching environment and to realize that I need to learn to enjoy my science courses so that I can instill that love of learning in my students.... Children learn by example, and I realized that I need to be that example to them." If our students could experience the epiphany that they should learn to enjoy their science courses at the beginning of the semester, we felt that the potential of the project could come closer to being realized.

For the second semester (Winter 2005), we tried to address these issues in several ways. First, we added more logistical information to the web site, gave them a short handout giving tips for creating a successful lesson (Figure 2), and mentored a better group dynamic via a worksheet that helped the groups make internal assignments and manage communication (Figure 1). We also included photographs of the previous semester's mini-lessons and positive comments made by the Principal and teachers at the elementary school into the class lectures and web site.

These changes appear to have had the desired effect. The results of the posttest open-ended question about which aspects of the class affected the student's attitude toward science (Table 2) were very similar to the results from the first semester (Table 1.) The mini-lesson project was still the most frequently listed factor for creating more positive attitudes. However, ATSS results from Winter 2005 showed a statistically significant improvement between the pretests and posttests, in contrast to those of Fall 2004. The difference in mean ATSS scores (2.4 points) from the pretest $($ Mean $=30.03$, $\mathrm{SD}=5.01)$ to the posttest (Mean $=32.43, \mathrm{SD}=4.82), \mathrm{t}=$ $-5.35, \mathrm{p}<.001$, was similar to that of the treatment group during the second semester (Winter 2004) of the study by Lusk et al. (2006). Although the treatment group during the first semester (Fall 2003) of Lusk's study showed a larger increase in mean ATSS scores (3.4 points), the 
treatment group represented only a small fraction of the total class because of the expense of hiring storybook illustrators. In contrast, we were able to include the entire class in the treatment described here.

Many students offered very encouraging comments about the effect the project had on them. For example, one student wrote that the teaching experience positively affected her attitude toward science "because I was able to apply 'why am I taking this class' instantly and directly." Another wrote that it "made me excited that I knew and could explain concepts to other people." Another wrote that it was her favorite part of the class because "It helped emphasize to me how fun it is to teach, and how important it is for the children to learn science and be excited about it."

These results have implications for similar studies. For example, in order to make our project truly successful, we had to tailor it to the learning style of the students in our class. Additionally, even if an idea for improving our classes does not seem to work well the first time, it may be that a few unexpected issues simply need to be resolved.

\section{CONCLUSIONS}

The Earth Science Mini-lesson project was implemented with the intention of involving the students in a real-world, useful project to improve student attitudes toward science. The project was successful in improving pre-service elementary teacher attitudes, but only after the specific learning style of the students was taken into account. In addition, there were no monetary costs required for running the project, and minimal extra instructor time was needed. Anyone desiring to run a similar project could simply adapt our web site (http:/ / www.geology.byu.edu/ps110b/presentation.ht $\mathrm{m})$, which includes all the materials needed.

During the next several semesters, we plan to run a design experiment (Brown, 1992; Cobb et al., 2003; Dede, 2005; Richey, 1997) where the project described in this paper will be the control. In addition to the mini-lesson project, students in future semesters will author children's storybooks as described by Lusk et al. (2006), but the illustrations will be created by the authors themselves, using common computer programs and an online catalog of characters, backgrounds, etc. Students will also have access to digital cameras and video cameras to take their own photographs or video footage to add to their multimedia storybooks. We feel that the addition of the multimedia project will further enhance the positive effect on preservice elementary teacher attitudes, capitalizing on the visual, global learning style of these students (Sloan et al., 2004).

\section{REFERENCES}

Abell, S. K., and Roth, M., 1994, Constructing science in the elementary school: The socialization of a science enthusiastic studen teacher, Journal of Research in Science Teaching, v. 31, p. 77-90.

Badura, A. S., Ware, M. E., Davis, S. F., and Smith, R. A., 2000, Teaching beyond the classroom: Mentoring student publications and presentations.

Beiswenger, R. E., Stepans, J. I., and McClurg, P. A., 1998, Developing science courses for prospective elementary teachers: An experimental program at the university of wyoming succeeds in preparing better science teachers, Journal of College Science Teaching, v. 27, p. 253-257.

Brown, A. L., 1992, Design experiments: Theoretical and methodological challenges in creating complex interventions in classroom settings, The Journal of Learning Sciences, v. 2, p. 141-178.

Brown, L. M., Kelso, P. R., and Rexroad, C. B., 2001, Introductory geology for elementary education majors utilizing a constructivist approach, Journal of Geoscience Education, v. 49, p. 450-453.

Bull, K. S., and Davis, G. A., 1980, Evaluating creative potential using the statement of past creative activities, Journal of Creative Behavior, v. 14, p. 249-257.

Cantrell, P., Young, S., and Moore, A., 2003, Factors affecting science teaching efficacy of preservice elementary teachers, Journal of Science Teacher Education, v. 14, p. 177-192.

Cherif, A., and Gialamas, S., 2000, "Creative final projects" in mathematics and science. Journal of College Science Teaching, v. 29, p. 272-278.

Cobb, P., Confrey, J., diSessa, A., Lehrer, R., and Schauble, L., 2003, Design experiments in educational research, Educational Researcher, v. 32, p. 9-13.

Coburn, W. W., and Loving, C. C., 2002, Investigation of preservice elementary teachers' thinking about science, Journal of Research in Science Teaching, v. 39 , p. 1016-1031.

Dede, C., 2005, Special issue: Why design-based research is both important and difficult, Educational Technology(January-February).

Dobey, D. C., and Schafer, L. E., 1984, The effects of knowledge on elementary science inquiry teaching, Science Education, v. 68, p. 39-51.

Drummond, C., 1999, Facilitating scientific thoughtfulness for non-science majors, Journal of Geoscience Education, v. 47, p. 45-55.

Dworkin, R. W., 2001, Science, faith, and alternative medicine, Policy Review, v. 108.

Erickson, J. A., and Anderson, J. B., 1997, Learning with the community: Concepts and models for service-learning in teacher education, Washington, DC: American Association for Higher Education.

Fones, S., Wagner, J., and Cladwell, E., 1999, Promoting attitude adjustments in science for pre-service elementary teachers, Journal of College Science Teaching, v. 28, p. 231-236.

Ginns, I. S., and Watters, J. J., 1996, Experiences of novice teachers: Changes in self-efficacy and their beliefs about teaching, Paper presented at the Annual Meeting of the American Educational Research Association, New York, NY.

Gosselin, D. C., and Macklem-Hurst, J. L., 2002, Pre-/ post-knowledge assessment of an earth science course for elementary/middle school education majors, Journal of Geoscience Education, v. 50, p. 169-175.

Greenblatt, E. L., 1962, An analysis of school subject preference of elementary school children of the middle grades, Journal of Educational Research, v. 55 , p. 554-560.

Haladyna, T., and Schaugnessy, J., 1982, Attitudes toward science: A quantitative synthesis, Science Education, v. 66, p. 547-563.

Hall, F. R., and Buxton, C. A., 2004, Advancing the revolution: Using earth systems science to prepare elementary school teachers in an urban 
environment, Journal of Geoscience Education, v. 52, p. 338-344.

Hannula, K. A., 2003, Revising geology labs to explicitly use the scientific method, Journal of Geoscience Education, v. 51, p. 194-200.

Havholm, K. G., 1998, An activity to introduce the geoscience perspective, Journal of Geoscience Education, v. 46, p. 137-140.

Holton, G., 1994, The antiscience problem, Skeptical Inquirer, v. 18, p. 264-265.

Kahle, J. B., 1984, Girls in school/women in science: A synopsis, Paper presented at the 8th Annual Women's Studies Conference, Greeley, CO.

Kahle, J. B., 1996, Opportunities and obstacles: Science education in the school, in C. Davis (Ed.), The equity of education: Fostering the advancement of women in the sciences, mathematics and engineering, San Fransisco, CA, Jossey Bass.

Kobolla, T. R., and Crawley, F. E., 1985, The influence of attitude on science teaching and learning, School Science and Mathematics, v. 85, p. 222-232.

Kusnick, J., 1999, The strategy column for precollege teachers: Teaching geoscience through literature, Journal of Geoscience Education, v. 47, p. 185-188.

Lusk, M. G., Bickmore, B. R., Christiansen, E. H., and Sudweeks, R. R., 2006, Use of a mentored creative writing project to improve the science education of preservice elementary teachers, Journal of Geoscience Education, v. 54, p. 31-40.

Madden, S. J., 2000, Service learning across the curriculum, Lanham, MD, University Press of America.

Manner, B. M., 1998, Academic preparation and confidence level of elementary-school science teachers, Journal of Geoscience Education, v. 46, p. 28-29.

Mestre, J. P., 1991, Learning and instruction in precollege physical science, Physics Today, v. 44, p. 56-62.

Metzger, E. P. (1996). The strategy column for precollege science teachers: Make your own paper trilobite. Journal of Geoscience Education, 44, 84-88.

Morris, M., Morrison, D. L., and Rosenberg, G. D., 2000, Lithographic limestone as a teaching tool, Journal of Geoscience Education, v. 48, p. 329-332.

National Research Council, 1996, National science education standards, National Academy Press.

National Science Foundation, 1997, Geoscience education: A recommended strategy, nsf 97-171, NSF 97-171.

NCLB, 2001, The elementary and secondary education act, no child left behind act of 2001, v. PL 107-110.

Osborne, M. D., and Brady, D. J., 2001, Constructing a space for developing a rich understanding of science through play, Journal of Curriculum Studies, v. 33, p. 511-524.

Payne, D. A., 2000, Evaluating service-learning activities and programs, Kent, England, Scarecrow Press, Inc.

Richey, R. C., 1997, Research on instructional development. Educational Technology, v. 45, p. 91-100.

Rischbieter, M. O., Ryan, J. M., and Carpenter, J. R., 1993, Use of microethnographic strategies to analyze some affective aspects of learning-cycle-based minicourses in paleontology for teachers, Journal of Geoscience Education, v. 41, p. 208-218.

Roth, W.-M., and McGinn, M., 1998, Undelete science education: / lives / work / voices, Journal of Research in Science Teaching, v. 35, p. 399-421.

Rule, A. C., 2005, Creativity skills applied to earth science education: Examples from k-12 teachers in a graduate creativity class, Journal of Geoscience Education, v. 53, p. 53-64.

Slater, T. F., Safko, J. L., and Carpenter, J. R., 1999, Long-term attitude sustainability from a constructivist-based astronomy-for-teachers course, Journal of Geoscience Education, v. 47, p. 366-368.

Slattery, W. A., 1996, A course for training preservice elementary teachers in the content and processes of earth science, Journal of Geoscience Education, v. 44, p. 259-261.

Stollberg, R., 1969, The task before us -- 1962, The education of elementary school teachers in science, in L. I. Kuslan and A. H. Tone (eds.), Readings on teaching children science, Belmont, CA, Wadsworth.

Tewksbury, B. J., 1998, Doing more than cloning ourselves - the need to reach all students, Journal of College Science Teaching, v. 46, p. 5-6.

Thompson, C. L., and Shrigley, R. L., 1986, Revising the science attitude scale, School Science and Mathematics, v. 86, p. 331-343.

van Zee, E. H., and Roberts, D., 2001, Using pedagogical inquiries as a basis for learning to teach: Prospective teachers' reflections upon positive science learning experiences, Science Education, v. 85, p. 733-757.

Wagner, J. R., and Caldwell, E. R., 2000, Science, in S. J. Madden (ed.), Service learning across the curriculum, Lanham, MD, University Press of America.

Westerback, M. E., 1982, Studies on attitude toward teaching science and anxiety about teaching science in preservice elementary teachers, Journal of Research in Science Teaching, v. 19, p. 603-616.

Westerback, M. E., 1984, Studies on anxiety about teaching science in preservice elementary teachers, Journal of Research in Science Teaching, v. 2, p. 937-950.

Westerback, M. E., and Long, M. J., 1990, Science knowledge and the reduction of anxiety about teaching earth science for exemplary teachers as measured by the science teachign state-trait anxiety inventory. School Science and Mathematics, v. 90, p. 361-374.

Wright, E., 2000, Making art and doing science in an undergraduate earth-science course, Journal of Geoscience Education, v. 48, p. 284-287.

Yager, R. E., 2000, A vision for what science education should be like for the first 25 years of a new millenium, School Science and Mathematics, v. 100, p. 327-341. 